\title{
Foreign Exchange Rate and Consumer Price Changes in the Nigerian Economy
}

\author{
Gbalam Peter Eze ${ }^{1}$, Dumani Markjackson ${ }^{2 *}$ \\ ${ }^{1}$ Department of Banking and Finance, Niger Delta University, Wilberforce Island, Bayelsa State, Nigeria \\ ${ }^{2}$ Department of Banking and Finance, Federal Polytechnic, Ekowe, PMB 110, Yenagoa, Bayelsa State, Nigeria
}

DOI: $10.36348 /$ sjef.2020.v04i02.001 | Received: 15.02.2020 | Accepted: 22.02.2020 | Published: 27.02 .2020

*Corresponding author: Dumani Markjackson

\section{Abstract}

This study examines the interactions between the general price level and foreign exchange rate in Nigeria. This was aimed at ascertaining if inflation was imported via the foreign exchange rate in Nigeria. The theoretical underpinning of this study was anchored on the purchasing power parity theory. The ex-post facto research design was adopted to observe the study variables in retrospect. Thus, historical data covering 1990 to 2018 was collated and estimated employing the error correction technique. The test results indicates that foreign exchange rate exert a positive and insignificant influence on the level of inflation in Nigeria. This stand to suggest that a benign level of change in the general price level is caused by imported inflation. Evidence further indicates that lending interest rate exerts a negative and significant impact on the level of inflation in Nigeria. The study concludes that persistent increase in foreign exchange rate stimulate increase in the general price level, whilst that of the lending interest rate has no bearing on the general price level in Nigeria. The policy implication of this is for the monetary authorities to ensure foreign exchange rate stability to avoid imported inflation. Also, the lending interest rate be made attractive enough to drive aggregate demand and not too unattractive to slow down aggregate demand. The study therefore recommends a stable and strong international and domestic value of the naira via a policy of stability.

Keywords: foreign exchange rate, general price level, lending interest rate, purchasing power parity, Nigeria.

Copyright @ 2020: This is an open-access article distributed under the terms of the Creative Commons Attribution license which permits unrestricted use, distribution, and reproduction in any medium for non-commercial use (NonCommercial, or CC-BY-NC) provided the original author and source are credited.

\section{INTRODUCTION}

The twin evil of inflation and foreign exchange rate exerts a double edged attack on the national currency of nations. Inflation attacks the local value of the national currency whereas; exchange rate attacks the international value of the national currency. On all fronts, this affects the economy of a nation adversely, and thus, this has been an herculean puzzle for policymakers. Thus, exchange rate and inflation management are cardinal areas of concern to central banks in developing countries of the world.

Exchange rate volatility breeds economic uncertainties and risks resulting from sudden upward or downward oscillation of the price of foreign currencies to the local currency. The severity of the fluctuations affects plethora of macroeconomic variables like raising manufacturing and service costs and investment risks, raising consumable prices, declining aggregate consumption, unfavourable trade payment positions, and a whole lot of others [1]. It also has adverse effect on economic efficiency, resource allocation and depletion of foreign exchange reserves [2]. The severity of connection the price of foreign currency has on other macroeconomic phenomenon is a major concern to policy makers. This makes it imperative to put in place a sound exchange rate policy regime to absorb possible shocks from the demand and supply of foreign exchange [3]. This is anchored on the grounds that foreign exchange rate stability engenders a policy of consumer price stability.

The Central Bank of Nigeria has over the years instituted various policy measures to protect the international value of the naira and other objectives of the bank. In view of this, lately, the bank introduced a policy of import restrictions and barred importers of several commodities from having access to foreign exchange. This was premised on the belief that foreign exchange should be made available only for commodities that cannot be sourced locally due to the depletion of the nation's intervention fund following falling international crude oil prices. Other policies of the bank include reduction of weekly allocation of US 
dollar to Bureau de Change operatives and reduction of withdrawal limit of foreign currency of plastic card users visiting overseas. Further to this are the multiple prices of foreign currency at different levels of the financial infrastructure that engages in buying and selling of foreign exchange in the nation. For instance, there is the apex bank rate which is regarded as the official foreign exchange rate, the I\&E window created in 2017, the black market rate and the interbank rate.

The consequence of these strategies caused plethora of volatility in the foreign exchange market which in turn has affected the value of the naira, foreign capital inflow, aggregate outputs, consumer prices and other macroeconomic phenomena in Nigeria. The crux of this paper therefore, is to ascertain the interaction between foreign exchange rate volatility and consumer price changes in Nigeria. This is informed by the fact that the value of the national currency of the nation has been relatively weak compared to her trading partners. Being that Nigeria is an importing nation, contrived scarcity and persistent raising prices of foreign exchange implies that importers of finished and intermediate products would buy at high prices and in order not to be at a loss would pass on the burden of high costs to the consumers. In view of this, this study intends to build a error correction model using time series data spanning 1981 to 2018 to examine the relationship between foreign exchange rate volatility and consumer price changes in Nigeria. A study of this nature would be a valuable addition to the compendium of extant literature on the topic. More importantly, it would give policymakers empirical insight on the dynamics between the twin evils of foreign exchange rate and consumer prices in Nigeria.

The remainder of the paper is structured as follows; section 2 presents theoretical underpinnings of the study, section 3 presents review of related empirical studies, section 4 describes the methodology of the study, section 5 presents results and findings and section 6 presents the concluding remarks of the study.

\section{THEORETICAL FRAMEWORK}

The theoretical underpinning of this study is anchored on the purchasing power parity theory. The Purchasing Power Parity theory was founded by Professor Gustav in the sixteenth century. The theory holds that the price of foreign exchange between two trading partners is a function of the relative value of their respective domestic currencies. The theorem implies that the foreign exchange rate, which is the price of foreign currency, will be at parity only when the relative buying powers of the currencies are at equilibrium. This in essence means that the Purchasing Power Parity theory tries to explain the relationship between foreign exchange rate and inflation or the price level.
The theory further holds that the determinant of foreign exchange rate in the long run is the relative price levels of two nations over a period of time [4]. This implies that the international value of a nation's currency depends on the local value of that currency over a span of time. The purchasing power or value of a currency depends on the forces of demand and supply.

However, the theory fails to capture shocks like price control, exchange rate bans or control and other forms of restrictions; thus, the foreign exchange rates may not be a real reflection of the purchasing power of two trading nations. Irrespective of this drawback, the theory provides relevant underpinnings on exchange rate studies [5].

\section{Review of Related Empirical Studies}

This section presents a review of related empirical studies on foreign exchange rate and consumer price changes.

Ebiringa and Anyaogu [4] examined the nexus between foreign exchange rate, lending interest rate, and price level in Nigeria. Secondary data spanning 39 years (1971 to 2010) was collated and estimated using the autoregressive distributive lag model. The results indicated the existence of a short and long run linear nexus between foreign exchange rate and price levels in Nigeria. It also emerged that lending interest rate exerted an insignificant nonlinear nexus with foreign exchange rate in Nigeria.

Abdurehman and Hacilar [6] examined the nexus between the level of inflation and foreign exchange rate in Turkey using generalized autoregressive conditional heteroskedasticity (GARCH) model. The results indicate lack of relationship between the inflation level and foreign exchange rate in Turkey. It further emerged that this may be as a result of government bans and other distortions.

Monfared and Akın [7] investigated the relationship between foreign exchange rate and inflation in Iran. Historical data spanning 1976 to 2012 was collated and the Hendry model and vector autoregressive model was used for the estimation. The Hendry results showed that there is a linear nexus between foreign exchange rate and the level of inflation in Iran. For the VAR model, the study introduced an additional explanatory variable, which revealed that foreign exchange rate and money stock exert a linear consequence on the prices of goods and services in Iran.

Sean, Pastpipatkul and Boonyakunakorn [8] examined the relationship that exists between money stock, rate of inflation and foreign exchange rate in Cambodia. Historical monthly data spanning October, 2009 to April, 2018 was collated and analysed employing the Bayesian vector autoregressive model. From the analyses it emerged that money stock exert a 
positive effect on foreign exchange rate and inflation in Cambodia. This means that increase in money supply devalues the international value of the Cambodian national currency, Khmer Riel against its trading partners. This in effect also makes the general price level to rise.

Bobai, Ubangida and Umar [9] examined the influence exchange rate fluctuation has on inflation in Nigeria using historical data spanning 1986 to 2010. The unit of analyses used for the estimation is the vector error correction technique. The results indicate that inflation bears a nonlinear impact on foreign exchange rate. This implies that increase in the general price level leads a decrease in the price of foreign exchange rate in Nigeria.

Nchor and Darkwah [10], used autoregressive distributed lag model and error correction model to examine the impact of foreign exchange rate fluctuations and nominal lending interest rate on the general price level in Ghana. Historical data spanning 1991 to 2013 was collated and estimated. The results show that foreign exchange rate exert direct positive effect on the rate of inflation in Ghana. This means that as the differential between the cedi and other national currencies increase, so does the general price level. Further results indicate that nominal lending interest rate exerts a decreasing effect on inflation. That is, every increase in interest rate makes the general price to decline disproportionately. However, it emerged that an increase in inflation leads to increase in the nominal lending interest rate in Ghana.

Timothy, Ada and Chigozie [11], used quarterly data from 1970 to 2014 to examine the effect of the general price level on real foreign exchange rate fluctuation in Nigeria. The variables employed were the level of inflation, import represented by imported inflation, money stock and foreign exchange rate. The historical data collated were analysed using the generalized autoregressive conditional heteroskedasticity and the granger causality techniques. The GARCH results found that the conditional variance of the real foreign exchange rate was vulnerable to lag, previous period error term and the other variables of the study. The causality results found that there is a one direction cause from the general price level to real foreign exchange rate. It also emerged that there is a nexus between import, real foreign exchange rate fluctuation and money stock in Nigeria.

Lado [12] investigated the relationship between foreign exchange rate and inflation in South Sudan using the granger causality technique. Monthly historical data spanning August, 2011 to November, 2014 was collated and estimated. The results indicate that foreign exchange rate cause increase in the rate of inflation in South Sudan. It further emerged that the relationship is not bidirectional, that is, rising prices does not cause changes in the price of foreign currency in South Sudan. This implies that as the value of the purchasing power in the country decrease, so does it cause an increase in the price of foreign exchange.

Bada, Olufemi, Tata, Peters, Sani Bawa and Onyowo [13] examined the role foreign exchange rate plays in influencing consumer prices and imports in Nigeria. Quarterly historical data spanning 1995 to 2015 was collated and analysed using the Johansen cointegration and vector error correction technique. The results portends that the exchange rate pass-through effect is more significant imports than aggregate inflation rate in Nigeria. The study concludes that the foreign exchange rate pass-through into aggregate inflation rate is incomplete in Nigeria.

Roger, Smith and Morrissey [14] examined the dynamic interaction between foreign exchange rate volatility and consumer price changes in Zambia. Secondary data spanning 1995 to 2014 was collected and estimated employing the structural vector autoregression technique. The findings indicate that foreign exchange rate bears a significant effect on aggregate inflation in Zambia. The study further averred that this effect is caused by the determinants of foreign exchange rate fluctuations in the country.

Shingil and Panshak [15] examined the nexus between foreign exchange rate, aggregate general price level and economic growth in Turkey. Historical data covering 1970 to 2015 was collated and estimated employing the autoregression distributed lag model and Toda-Yamamoto granger non-causality techniques. The findings indicate that in the long run, real effective exchange rate stimulate a substantial linear effect on output growth, whereas the reverse is the case in the short run. Findings also indicate real foreign exchange rate granger cause economic growth in Turkey. This implies that the main subjects behind the need for foreign exchange stimulate capital formation and invariably cause national output growth in the country.

Moroşan and Zubaş [16] examined the link between lending interest rate, foreign exchange rate and general price level in Romania using the multiple regression technique following the ordinary least square example. Historical data spanning 2005 to 2014 was collated and estimated using the unit of analysis. The findings indicate that increase in the general price level led to increase in the lending interest rate. This means that there is a positive relationship between inflation and lending interest rate in Romania. It further emerged that foreign exchange rate exert a positive effect on the cost of credit. This implies that as the price of foreign exchange increases, so does it elevate the cost of credit in Romania. 
Fetai, Koku, Caushi and Fetai [17] examined the link between foreign exchange rate and the general price level in Western Balkan countries. The specific target of the study was to determine if flexible or fixed foreign exchange rate stimulate a change in the general price level in the sampled countries. Secondary quarterly data spanning 1996 to 2014 was collated and pooled for all the Western Balkan nations. The analyses were done using the panel regression technique. The findings indicate that foreign exchange rate exert a positive bearing on inflation. Specifically, the analyses show that flexible exchange rate is the main source of changes in the price level in the economic block.

Yakub, Sani, Obiezue and Aliyu [18] examined the effect of foreign exchange rate fluctuations on trade flows in Nigeria. Historical monthly data spanning 1997 to 2016 was collated. The study employed GARCH model to generate the volatility series, ARDL to determine the long run equilibrium relationship and the granger causality to determine the direction of causality in the models. Findings indicate that foreign exchange rate exert a positive impact on trade flows in the long run; however, in the short run, the link was found to be nonlinear. This implies that an increase in the price of foreign exchange rate adversely affect imports and export in Nigeria.

Adetiloye [19] investigated the link between foreign exchange rate and the general price level in Nigeria. The specific objective was to ascertain the nexus between the official and parallel foreign exchange rate and the rate of inflation in Nigeria. Correlation and granger causality technique was used for the analyses. The findings show that there is a more significant relationship between the proportion of imports and the general price level. Comparatively, the relationship was found to have lesser amount of significance in the case of the black market rate.

Omotor [20] investigated the influence of exchange rate fluctuations on prices changes in Nigeria. The study used historical data spanning 1970 to 2003 and employed the Vector Error Correction, forecast error variance decomposition and slope dummy method of data estimation technique to ascertain the impact of foreign exchange rate on aggregate consumer prices in Nigeria. The VEC results indicate that inflation in Nigeria may have determined by various exchange rate policy regimes. The slope dummy results validated this finding. Furthermore, the variance decomposition results showed that broad money stock and foreign exchange rate exert a significant impact on inflation than the level of output in Nigeria.

Akinbobola [21] examined the interaction between money stock, foreign exchange rate and aggregate consumer prices in Nigeria using quarterly data spanning 1986 to 2008. The model was estimated using the vector error correction method. The dependent variable is expected rate of inflation while the independent variables are broad money supply, growth in real output, foreign exchange rate and foreign prices. The long run results indicate that the stock of money supply and foreign exchange rate exert a significant opposite (or indirect) impact on inflation. It also emerge that there is a causal connection between foreign exchange rate, broad money stock and the aggregate price level in Nigeria.

Onwuka and Igweze [22] investigated the impact of external reserves and sovereign debt on foreign exchange rate in Nigeria. The dependent variable is exchange rate while the independent variables were foreign reserves and foreign debt. The multiple regress technique was used for the data analysis and estimation. The results show that external reserves and debt exert a positive significant impact foreign exchange rate in Nigeria.

Ogundipe and Samuel [23] investigated the impact of foreign exchange rate and inflation in Nigeria. The variables used in the analyses are the nominal effective exchange rate, real official exchange rate, broad money supply and consumer price index. The structural vector autoregressive and variance decomposition techniques were used for the analyses. It emerged that foreign exchange rate pass-through to the general price level. This implies foreign exchange rate plays a significant role in influencing the aggregate price level than money supply in Nigeria.

Imimole and Enoma [24] set out to ascertain the effect of foreign exchange rate fluctuations on the general price level in Nigeria using the autoregressive distributed lag model. Historical data on inflation, the dependent variable while the independent variables were broad money supply, gross domestic product at constant rate, exchange rate, public expenditure and lag inflation spanning 1986 to 2008 was collated for this purpose. The results averred that foreign exchange rate, money supply, gross domestic product at its constant exerts significant impact on the changes in the consumer price level in Nigeria. Specifically, the results indicated that foreign exchange rate has linear significant impact on inflation in Nigeria. This implies that as the value of the naira declines substantially against other national currencies, so does it translate to increase in domestic prices via imported inflation in Nigeria.

Abdullateef and Waheed [25] examined the influence of fluctuations in foreign reserves on domestic investments, aggregate price level and foreign exchange rate in Nigeria. Historical data was collated and analysed using the ordinary least square technique in conjunction with the vector error correction method. The results indicated that fluctuations in external reserves exert significant impact on capital inflow and 
foreign exchange rate and that it has no bearing on the aggregate price level.

\section{METHODOLOGY \\ Research Design}

The ex-post facto research design was employed to examine the interaction of the variables of the study. Ex-post facto research design is a quasiexperimental design used in examining how study variables interact in retrospect. Consequently, this research design was adopted due to the fact that researcher has no control over the regulations, policies and the behaviour of the numeric values of the variables of the study. Thus, this design enabled the researcher to collate data and use econometric techniques to observe and coagulate the series, ascertain the long run nexus and estimate the direction and magnitude of the variables of the study.

\section{Nature and Source of Data}

The nature of the data collated for the analyses is historical time series data spanning 1990 to 2018 . The data was collated from the survey of a secondary source called the World Development Indicators. Specifically, data on foreign exchange rate, aggregate consumer prices and real lending interest rate were collated to examine their interactions.

\section{Model Specification}

Following extant literature, the study employed the multiple regression technique to determine the direction and magnitude of the interaction between the general price level and the explanatory variables of foreign exchange rate and real lending interest rate in Nigeria.

The functional model is expressed as;

$I N F L=f(E X C R, R I R)$

This is further transformed to an econometric model as; $I N F L_{t}=a_{0}+a_{1} E X C R_{t}+a_{2} R I R_{t}+u_{t}$

Where;

$\mathrm{a}_{0}$ is the intercept of the model, $\mathrm{a}_{1}-\mathrm{a}_{2}$ are the coefficients of the explanatory indicators, $t$ is the time series and $u$ is the error term of the model.

INFL is inflation level, the measure of consumer prices.
EXCR is foreign exchange rate, the measure of the price of foreign exchange.

RIR is real lending interest rate, the measure of the cost of credit.

\section{Econometric Results}

Descriptive Statistics

Table-1 presents the results of the descriptive statistics of the variables of the study.

Table-1: Descriptive Statistics Results

\begin{tabular}{|l|c|c|c|}
\hline & EXCR & INFL & RIR \\
\hline Mean & 115.2871 & 17.83777 & 3.078756 \\
\hline Median & 125.8081 & 10.23475 & 6.047248 \\
\hline Maximum & 306.0837 & 75.40165 & 18.18000 \\
\hline Minimum & 8.038285 & 0.686099 & -31.45257 \\
\hline Std. Dev. & 83.09255 & 16.41542 & 10.81483 \\
\hline Skewness & 0.576690 & 1.833063 & -1.294644 \\
\hline Kurtosis & 2.996211 & 6.489734 & 4.922639 \\
\hline Jarque-Bera & 1.607447 & 30.95596 & 12.56782 \\
\hline Probability & 0.447659 & 0.000000 & 0.001866 \\
\hline Sum & 3343.325 & 517.2953 & 89.28391 \\
\hline Sum Sq. Dev. & 193322.4 & 7545.050 & 3274.897 \\
\hline Observations & 29 & 29 & 29 \\
\hline
\end{tabular}

Source: Researcher's computation

The results indicate that the observations are equal. The mean average of the measures of the study reads EXCR (115.2871), INFL (17.83777) and RIR (3.078756). Jarque-Bera statistics indicate that, apart from INFL and RIR which are statistical zero, EXCR is normally distributed. The results further indicate that, apart from RIR, all the other measures of the study are positively skewed.

The standard deviation gauges the unevenness of the variables of the study from period to period show as follows; EXCR (83.09255), INFL (16.41542) and RIR (10.81483). Further observations indicate that EXCR is dispersed around the median and the mean value, INFL is dispersed above the middle value and a little below the mean value and finally, RIR is dispersed above the median and mean value.

\section{Augmented Dickey-Fuller Statistics}

The summary unit root test statistics of the variables are presented in Table-2.

Table-2: Summary Augmented Dickey-Fuller Test Results

\begin{tabular}{|l|l|l|l|l|}
\hline Variables & ADF Statistics & $\begin{array}{l}\text { Critical Value @ } \\
\mathbf{5 \%}\end{array}$ & Probability & Decision \\
\hline EXCR & -3.871025 & -3.587527 & 0.0278 & $\mathrm{I}(1)$ \\
\hline RRDL & -3.757975 & -3.603202 & 0.0367 & $\mathrm{I}(1)$ \\
\hline LIR & -3.918701 & -3.603202 & 0.0264 & $\mathrm{I}(1)$ \\
\hline
\end{tabular}

Source: Researcher's computation 
The results indicate that all the variables are stationary at their first difference. This is symbolized as $\mathrm{I}(1)$.

\section{Johansen Co-integration Test Results}

The Johansen co-integration test results of the study are presented in Table-3.

Table-3: Summary Johansen Co-integration Test Results

\begin{tabular}{|c|c|c|c|c|}
\hline \multicolumn{5}{|c|}{ Date: 02/03/20 Time: 09:20 } \\
\hline \multicolumn{5}{|c|}{ Sample (adjusted): 19922018} \\
\hline \multicolumn{5}{|c|}{ Included observations: 27 after adjustments } \\
\hline \multicolumn{5}{|c|}{ Trend assumption: Linear deterministic trend } \\
\hline \multicolumn{5}{|c|}{\begin{tabular}{|l|l|} 
Series: INFL EXCR RIR & \\
\end{tabular}} \\
\hline \multicolumn{5}{|c|}{ Lags interval (in first differences): 1 to 1} \\
\hline \multicolumn{5}{|c|}{ Unrestricted Cointegration Rank Test (Trace) } \\
\hline Hypothesized & & Trace & 0.05 & \\
\hline No. of CE(s) & Eigenvalue & Statistic & Critical Value & Prob.** \\
\hline None $*$ & 0.491260 & 32.09442 & 29.79707 & 0.0267 \\
\hline At most 1 & 0.393895 & 13.84732 & 15.49471 & 0.0872 \\
\hline At most 2 & 0.012089 & 0.328384 & 3.841466 & 0.5666 \\
\hline
\end{tabular}

Source: Researcher's computation

The test results show that there is a long run equilibrium relationship in the model. Precisely, the test results revealed 1 co-integrating relationships in the model. This gives econometric credence to carry out the error correction process.

\section{Error Correction Results}

Table-5 presents the results of the error correction process estimated using the least square technique.

Table 5: Error Correction Mechanism Results

\begin{tabular}{|c|c|c|c|c|}
\hline \multicolumn{5}{|c|}{ Dependent Variable: D(INFL) } \\
\hline \multicolumn{5}{|c|}{ Method: Least Squares } \\
\hline \multicolumn{5}{|c|}{ Date: 02/03/20 Time: 10:06 } \\
\hline \multicolumn{5}{|c|}{ Sample (adjusted): 19912018} \\
\hline \multicolumn{5}{|c|}{ Included observations: 28 after adjustments } \\
\hline Variable & Coefficient & Std. Error & t-Statistic & Prob. \\
\hline $\mathrm{C}$ & -0.652444 & 0.863525 & -0.755558 & 0.4573 \\
\hline $\mathrm{D}(\mathrm{EXCR})$ & 0.014947 & 0.038758 & 0.385662 & 0.7031 \\
\hline $\mathrm{D}(\mathrm{RIR})$ & -1.429153 & 0.072096 & -19.82304 & 0.0000 \\
\hline ECM(-1) & -1.049852 & 0.192022 & -5.467364 & 0.0000 \\
\hline R-squared & 0.943820 & \multicolumn{2}{|c|}{ Mean dependent var } & 0.127350 \\
\hline Adjusted R-squared & 0.936798 & \multicolumn{2}{|c|}{ S.D. dependent var } & 15.98694 \\
\hline S.E. of regression & 4.019134 & \multicolumn{2}{|c|}{ Akaike info criterion } & 5.751574 \\
\hline Sum squared resid & 387.6825 & \multicolumn{2}{|c|}{ Schwarz criterion } & 5.941888 \\
\hline Log likelihood & -76.52203 & \multicolumn{2}{|c|}{ Hannan-Quinn criter. } & 5.809755 \\
\hline F-statistic & 134.3995 & \multicolumn{2}{|c|}{ Durbin-Watson stat } & 1.887264 \\
\hline Prob(F-statistic) & 0.000000 & & & \\
\hline
\end{tabular}

Source: Researcher's computation

The test results indicate that the adjusted coefficient of determinant caused a $94 \%$ variation in general price level is explained by the independent variables. This means that $6 \%$ of variation is explained by measures not captured in the model. The coefficient of the adjusted $\mathrm{R}^{2}$ further specifies that the model is well fitted.

The DW statistics of 1.887264 indicated the absence of first order serial autocorrelation. This further corroborated by the Breusch-Godfrey Serial Correlation LM test. The Breusch-Pagan-Godfrey diagnostic test for heteroskedasticity also indicated the absence of heteroskedasticity. These diagnostic test results are presented in appendices $1 \& 2$ respectively.

Furthermore, the test of the overall significance of the model showed that the model is statistically significant. This was indicated by the Fisher's ratio of 134.3995 with a corresponding probability value of zero. Expectedly, the coefficient of the error correction term follows the a priori position, which is negative. This implies that the model has the capacity to adjust to equilibrium. The test results specifically averred that a 1.049852 speed of adjustment to equilibrium. 


\section{The coefficients and the t-Statistics results further indicated the following;}

Foreign exchange rate (EXCR) captures the price (or otherwise the cost) of acquiring foreign currency for international transactions. The variable showed that the rate exert a positive impact on the general price level. Although the t-Statistics indicated that the positive impact is statistically insignificant in causing price increase in Nigeria. This is indicative of the fact that, the coefficient of foreign exchange rate positive and the p-value is above the $5 \%$ tolerable level of significance. This result is consistent with the findings of Monfared and Akın [7], Nchor and Darkwah [10], Lado [12] and Roger et al., [14]. This present study like the ones cited above holds that exchange rate portend a direct bearing on the general price level. This implies that as the price differential between the local currency and international or foreign currency spreads wider, so does it intensify the general price level. This follows closely that as the value of the local currency depreciates or loose it value to the international currency, so does it lead to increase in prices due to imported inflation in Nigeria.
Real interest rate (RIR) captures the cost of credit in the economy. The test results indicate that the variable exerts a negative and statistical significant impact on consumer prices changes in Nigeria. This is indicative of the negative coefficient of the lending interest rate with a p-value that is below the 5\% acceptable level of significance. This means that increase and or decrease in the lending interest rate does not have any direct consequence on the general price level but rather the results indicate that increase in the real lending interest rate lead to a decline in the price level of the country. This implies that increase in the lending interest rate makes credit unattractive to households, businesses and other deficit economic units of the countries, and thus, has the tendency to reduce spending and the general price level of the country. That is, every increase in interest rate makes the general price to decline disproportionately. This follows closely to extant economic theory. This was corroborated by Nchor and Darkwah [10] study, which established a nonlinear relationship between the general price level and lending interest rate in Ghana.

Appendix 1: Breusch-Godfrey Serial Correlation LM Test

\begin{tabular}{|l|l|l|l|}
\hline \multicolumn{2}{|l|}{ Breusch-Godfrey Serial Correlation LM Test: } & \\
\hline F-statistic & 0.114931 & Prob. F(2,22) & 0.8920 \\
\hline Obs*R-squared & 0.289527 & Prob. Chi-Square(2) & 0.8652 \\
\hline
\end{tabular}

Appendix 2: Heteroskedasticity Test: Breusch-Pagan-Godfrey

\begin{tabular}{|l|l|l|l|}
\hline \multicolumn{4}{|l|}{ Heteroskedasticity Test: Breusch-Pagan-Godfrey } \\
\hline F-statistic & 0.641996 & Prob. F(3,24) & 0.5955 \\
\hline Obs*R-squared & 2.080062 & Prob. Chi-Square(3) & 0.5560 \\
\hline Scaled explained SS & 1.183819 & Prob. Chi-Square(3) & 0.7569 \\
\hline
\end{tabular}

\section{CONCLUSION}

This study examines the interactions between the general price level and foreign exchange rate in Nigeria. This was marked at ascertaining if inflation was imported via the foreign exchange rate in Nigeria. Thus, historical data covering 1990 to 2018 was collated and estimated employing the error correction technique. The test results indicates that foreign exchange rate exert a positive and insignificant influence on the level of inflation in Nigeria. This stand to suggest that a benign level of changes in the general price level is caused by imported inflation. Evidence further indicates that lending interest rate exerts a negative and significant impact on the level of inflation in Nigeria. The study concludes that persistent increase in foreign exchange rate stimulate increase in the general price level, whilst that of the lending interest rate has no bearing on the general price level in Nigeria. The policy implication of this is for the monetary authorities to ensure foreign exchange rate stability to avoid imported inflation. Also, the lending interest rate be made attractive enough to drive aggregate demand and not too unattractive to slow down aggregate demand. The study therefore recommends a stable and strong value of the international and domestic value of the naira via a policy of stability.

\section{REFERENCES}

1. Oseni, I. O. (2016). Exchange rate volatility and private consumption in Sub-Saharan African countries: A system-GMM dynamic panel analysis. Future Business Journal, 2, 103-115.

2. Elahi, N., Salimi, F., \& Masoomzadeh, E. (2016). Investigating asymmetric effects of monetary shocks on the exchange rate and trade balance, with an emphasis on inflation targeting. 1st International Conference on Applied Economics and Business, ICAEB, 2015. 36, 165-176. Procedia Economics and Finance.

3. Soe, T. T., \& Kakinaka, M. (2018). Inflation targeting and exchange market pressure in developing economies: Some international evidence. Finance Research Letters, 24, 263-272.

4. Ebiringa, O. T., \& Anyaogu, N. (2014). Exchange rate, inflation and interest rates relationships: An autoregressive distributed lag analysis. Journal of Economics and Development Studies, 2(2), 263279. 
5. Nucu, A. (2011). Relationship between exchange rate and key macroeconomic indicators: Case study Romania. The Romanian Economic Journal, 14(41), 127-145.

6. Abdurehman, A. A., \& Hacilar, S. (2016). The relationship between exchange rate and inflation: An empirical study of Turkey. International Journal of Economics and Financial Issues, 6(4), 1454-1459.

7. Monfared, S. S., \& Akın, F. (2017). The relationship between exchange rates and inflation: The case of Iran. European Journal of Sustainable Development, 6(4), 329-340.

8. Sean, M., Pastpipatkul, P., \& Boonyakunakorn, P. (2019). Money supply, inflation and exchange rate movement: The case of Cambodia: Bayesian var approach. Journal of Management, Economics, and Industrial Organization, 3(1), 63-81.

9. Bobai, F. D., Ubangida, S., \& Umar, Y. S. (2013). An assessment of exchange rate volatility and inflation in Nigeria. Journal of Emerging Issues in Economics, Finance and Banking, 1(4), 321-340.

10. Nchor, D., \& Darkwah, S. A. (2015). Inflation, exchange rates and interest rates in Ghana: An autoregressive distributed lag model. Acta Universitatis Agriculturae Et Silviculturae Mendelianae Brunensis, 63(3), 969-977.

11. Timothy, O. T., Ada, M. S., \& Chigozie, A. O. (2016). Exchange rate volatility and inflation: The Nigerian experience. Journal of Economics and Sustainable Development, 7(10), 6-15.

12. Lado, E. P. (2015). Test of relationship between exchange rate and inflation in South Sudan: Granger-Causality approach. Economics, 4(2), 3440.

13. Bada, A. S., Olufemi, A. I., Tata, I. A., Peters, I., Sani Bawa, A. J., \& Onyowo, U. C. (2016, June). Exchange rate pass-through to inflation in Nigeria. CBN Journal of Applied Statistics, 7(1(a)), 49-70.

14. Roger, L., Smith, G., \& Morrissey, O. (2017). Exchange Rate and Inflation Dynamics in Zambia. Macroeconomics and Fiscal Management Global Practice Group. Washington DC: World Bank Group.

15. Shingil, M. E., \& Panshak, Y. (2017). Exchange rate dynamics, inflation and economic growth:
Empirical evidence from Turkish economy. IOSR Journal of Humanities and Social Science, 22(9), 42-49.

16. Moroşan, G., \& Zubaş, I. M. (2015). Interest rate, exchange rate and inflation in Romania: Correlates and interconnection. Journal of Public Administration, Finance and Law, (8), 146-160.

17. Fetai, B., Koku, P. S., Caushi, A., \& Fetai, A. (2016). The relationship between exchange rate and inflation: The case of Western. Journal of Business, Economics and Finance, 5(4), 360-364.

18. Yakub, M. U., Sani, Z., Obiezue, T. O., \& Aliyu, V. O. (2019). Empirical investigation on exchange rate volatility and trade flows in Nigeria. Central Bank of Nigeria Economic and Financial Review, 57(1), 23-46.

19. Adetiloye, K. A. (2010). Exchange rates and the consumer price index in Nigeria : A causality approach. Journal of Emerging Trends in Economics and Management Sciences, 1(2), 114 120.

20. Omotor, D. G. (2008). Exchange rate reform and its inflationary consequences: The case of Nigeria. Ekonomski Pregled, 59(11), 688-716.

21. Akinbobola, T. (2012). The dynamics of money supply, exchange rate and inflation in Nigeria. Journal of Applied Finance \& Banking, 2(4), 117 141.

22. Onwuka, E. M., \& Igweze, A. H. (2014). Impact of external reserve and foreign debt on Naira exchange rate. Journal of International Academic Research for Multidisciplinary, 2(1), 416-423.

23. Ogundipe, A. A., \& Samuel, E. (2013). Exchange rate pass-through to consumer prices in Nigeria. Journal of Business Management and Applied Economics, II(4), 1-10.

24. Imimole, B., \& Enoma, A. (2011). Exchange rate depreciation and inflation in Nigeria (1986-2008). Business and Economics Journal, 28, 1-12.

25. Abdullateef, U., \& Waheed, I. (2010). External reserve holdings in Nigeria: Implications for investment, inflation and exchange rate. Journal of Economics and International Finance, 2(9), 183189. 